\title{
Bauxite in Areas
}

Adjacent to and Between the Springvale and Andersonville Districts Georgia

GEOLOGICAL SURVEY BULLETIN 1199-H

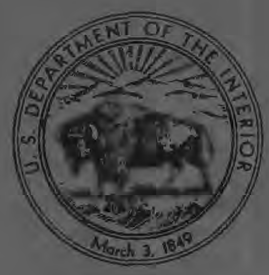




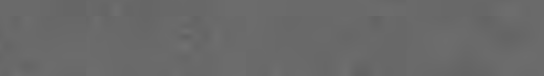

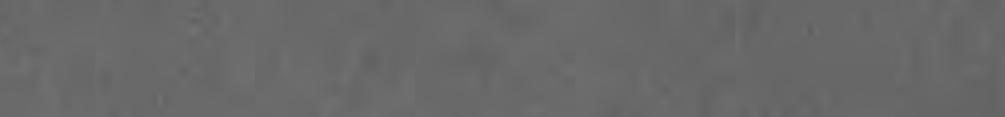

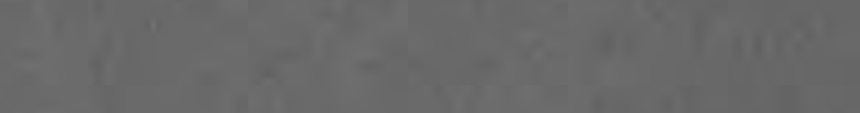

$$
\begin{aligned}
& f^{2} \\
& x^{2} x^{-4}=
\end{aligned}
$$




\section{Bauxite in Areas}

Adjacent to and Between the Springvale and Andersonville Districts Georgia

By ALFRED D. ZAPP and LORIN D. CLARK

BAUXITE DEPOSITS OF THE SOUTHEASTERN UNITED STATES

GE OL O G C A L S U R VEY B U L L E T I N 1199-H

Distribution and occurrence

of low-grade bauxite deposits

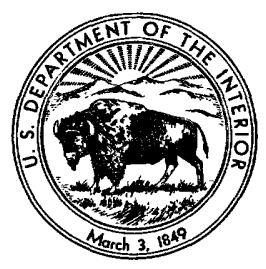


UNITED STATES DEPARTMENT OF THE INTERIOR

STEWART L. UDALL, Secretary

\author{
GEOLOGICAL SURVEY
}

Thomas B. Nolan, Director

For sale by the Superintendent of Documents, U.S. Government Printing Office Washington, D.C. 20402 


\section{CONTENTS}

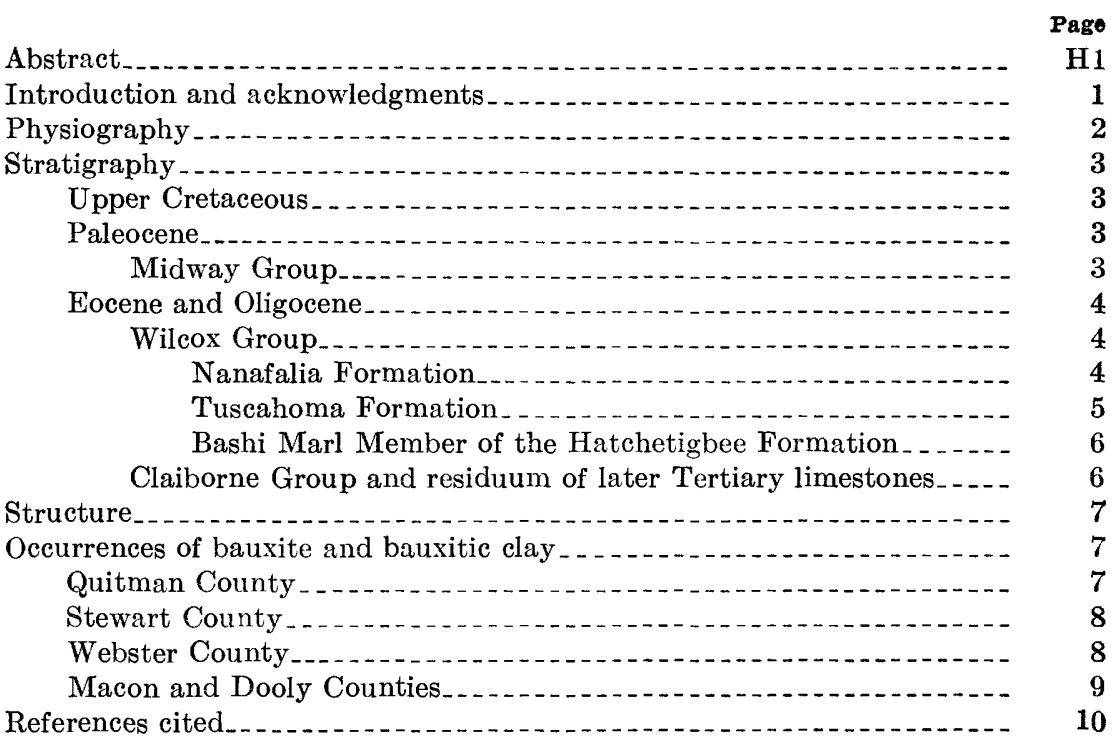

\section{ILLUSTRATIONS}

Plate 1. Geologic map of the area from the Chattahoochee River in Clay and Quitman Counties to Peach County, Ga_.... In pocket

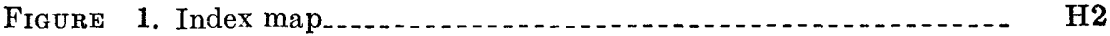




.




\title{
BAUXITE DEPOSITS OF THE SOUTHEASTERN UNITED STATES
}

\section{BAUXITE IN AREAS ADJACENT TO AND BETWEEN THE SPRINGVALE AND ANDERSONVILLE DISTRICTS, GEORGIA}

\author{
By Alfred D. Zapp and Lorin D. Clark
}

\begin{abstract}
Scattered small deposits of low-grade bauxite and bauxitic clay of little potential economic importance occur in a strip that extends northeastward between and beyond the Springvale and Andersonville bauxite districts. This strip includes parts of Clay, Quitman, Stewart, Webster, Sumter, Marion, Schley, and Macon Counties; its northeastern extremity extends just into Peach County, near the central part of Georgia.

As in the Andersonville and Springvale bauxite districts, the bauxite occurs within koalin bodies in the continental beds of the Nanafalia Formation (Wilcox Group of early Eocene age), which is overlain by marine sands and clays of the Tuscahoma Formation (middle Wilcox) and underlain by marine sands, clays, and limestones of the Midway Group of Paleocene age. Over most of the area of this report, the Nanafalia Formation is very thin or absent; in many places the remnants of the Nanafalia, with the included bauxite, apparently occur in sinkholes that formed in the limestone of the underlying Midway mostly before deposition of the Tuscahoma Formation.

The stratigraphy of the area is characterized by northward and eastward thinning of the Tuscahoma Formation and the Midway Group. As the entire strip was covered by overlapping sands of middle Eocene age and limestones of late Eocene and Oligocene ages, the lower Eocene and Paleocene beds are exposed only in the stream valleys.
\end{abstract}

\section{INTRODUCTION AND ACKNOWLEDGMENTS}

The U.S. Geological Survey and U.S. Bureau of Mines undertook a joint program of bauxite exploration in the Southeastern United States during and after World War II. As a part of this program, the Springvale (Clark, 1965) and Andersonville (Zapp, 1965) districts were investigated, and after completion of detailed mapping, the study was extended into the intervening area; a strip including all known occurrences of bauxitic material in southwestern Georgia was mapped in moderate detail. The area west of the Stewart County-Webster County line (pl. 1) was mapped by L. D. Clark and, east of that line (pl. 1), by A. D. Zapp. The locations of these areas are shown in figure 1 . 


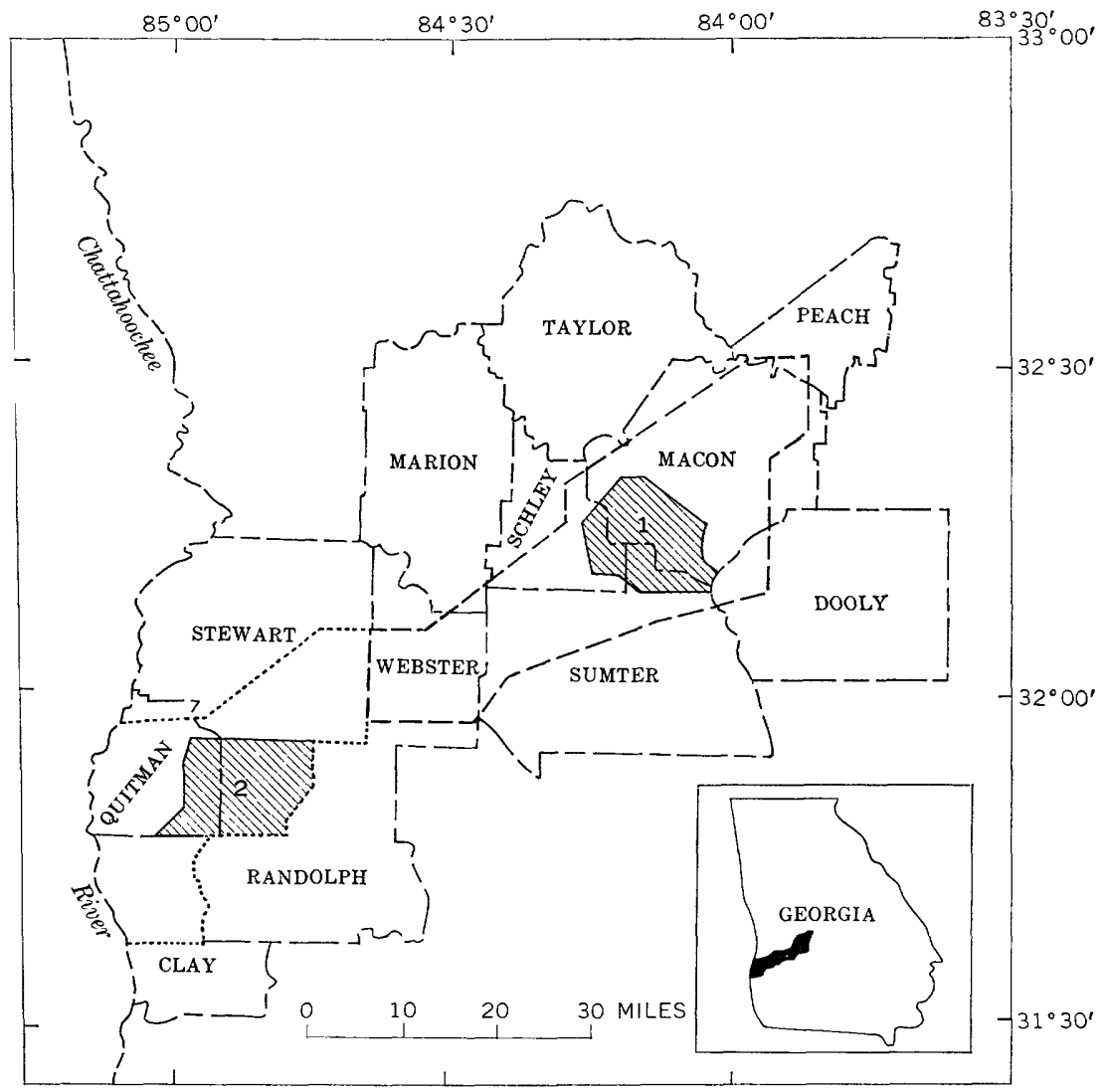

Figure 1.-Part of Georgia from the Chattahoochee River to Webster County (dotted line) and from Stewart County to Peach County (dashed line). Shaded areas indicate Andersonville district (1) and Springvale district (2).

During the summer of 1942, Mr. J. I. Tracey, Jr., of the Geological Survey made a preliminary investigation of the whole area and mapped part of it. The writers have drawn freely from Tracey's field notes and maps. The writers also profited greatly from the stratigraphic work in the area by MacNeil (1947), also of the Geological Survey.

\section{PHYSTOGRAPHY}

In general the area is one of low relief, characterized by wide, rather shallow stream valleys cut into a plain that dips gently southeastward. The Baker Hill cuesta, most prominent in the Eufaula district, Alabama, extends into and is also prominent in Clay and southern Randolph Counties but is less distinct in northern Randolph County and eastward. Natural exposures of bedrock are few and generally very 
poor. Adjacent to the Chattahoochee River, excellent exposures, however, occur in large gullies that have cut through the upper Eocene sand into the top of the Upper Cretaceous rocks.

In Clay and Quitman Counties, several terrace levels of the Chattahoochee River are evident. A dip slope, formed at the top of the Midway Group, extends from the north border of Clay County into southern Quitman County. The north end of the dip slope is dissected, whereas the south end is buried by terrace deposits.

Sinkholes, formed by subsurface leaching of limestone of the Midway Group, are common southeast of the outcrop belt of the Midway Group.

\section{STRATIGRAPHY}

The succession and general lithologic character of the formations are about the same as in the Andersonville and Springvale districts. The areal extent of these formations is shown on plate 1.

\section{UPPER CRETACEOUS}

The area shown as Upper Cretaceous on the accompanying maps is, for the most part, the outcrop area of the Providence Sand. Dark marine sediments of the underlying Ripley Formation also crop out in some of the deeper stream valleys near the northwest and northeast edges of the area. These two formations are mapped as a single unit.

The Providence Sand consists chiefly of light-colored sands, kaolinitic sandy clays, and kaolin. The amount of kaolin in the formation increases somewhat in a northeasterly direction.

\section{PALEOCENE}

\section{MIDWAY GROUP}

The thickness of the Midway Group, represented only by the Clayton Formation, decreases gradually to the northeast along the strike, and the general lithologic character changes from predominantly calcareous to predominantly argillaceous. Widespread subsurface leaching of the limestone, especially along present valleys, has made it impossible to obtain accurate measurements of the original thickness of the Midway from surface exposures. In Stewart County and to the southwest, the Midway in most places is represented by a basal member of coarse red sand overlain by 10 to 25 feet of contorted deep-red and olive-drab clays and sands that are the residue from solution of the limestone. From the vicinity of the town of Plains, Sumter County, about halfway between the Andersonville and Springvale bauxite districts, southeastward into the Kinchafoonee Creek valley, the sediments 
overlying the Midway Group sag as much as 60 feet. This sagging indicates that at least 60 feet of limestone, formerly present in the Midway here, has been dissolved away. The total remaining thickness here is probably about 90 feet. The only good exposures of limestone in the area shown on plate 1 are in northeastern Clay County near Garnersville.

In the northeastern part of the area (pl. 1), for a distance of about $21 / 2$ miles northward from Montezuma, the Midway Group is exposed along the Flint River escarpment where it averages about 45 feet in thickness and contains approximately equal amounts of limestone and clay. Farther north the limestone has been leached away, and exposures show only 15 to 25 feet of clay and residual material. The solution of limestone of the Clayton is reflected in numerous circular depressions on the surface of the plateau in this region.

Northeast and northwest of the town of Marshallville in the extreme northeastern part of the area (pl. 1), 10 to 20 feet of dark silty clay or laminated fine sand of the Midway Group is present nearly everywhere between the sand of the Claiborne Group and the Providence Sand of Late Cretaceous age. The Midway sediments become increasingly coarse in texture and spotty in occurrence northeastward and northward and wedge out entirely a few miles beyond the northeast margin of plate 1.

\section{EOCENE AND OLIGOCENE}

WILCOX GROUP

\section{NANAFALIA FORMATION}

The Nanafalia Formation is of marine origin at Fort Gaines (pl. 1), but 2 or 3 miles north of Fort Gaines it grades into continental deposits similar to those that compose the formation elsewhere in the area mapped.

Remnants of the Nanafalia Formation are irregularly distributed, and some of the remnants contain small lenses of kaolin and bauxite. In much of the western two thirds of the mapped area, the Nanafalia Formation is absent, and the Midway Group is overlain directly by the Tuscahoma Formation. Where present most of the Nanafalia sediments probably lie in pre-Tuscahoma depressions in the upper surface of the Midway Group. As the Nanafalia Formation occurs only sporadically and is associated with sinkhole structures in the Midway Group, the two units have been mapped together in this part of the area.

From Muckalee Creek northeastward to the Andersonville district, the Nanafalia forms a continuous blanket averaging 20 to 30 feet in 
thickness. Kaolin is present in several places in the Muckalee Creek drainage, but no bauxite has been found there.

The Nanafalia Formation is more uniformly present along the southeast edge of the area mapped (pl. 1) and presumably thickens southeastward. Southeast of a straight line between Springvale and Andersonville, the Nanafalia is largely concealed by younger sediments; it is possible that the formation in that area is thick and contains deposits of bauxite comparable to those of the Andersonville and Springvale districts.

The entire Nanafalia Formation is exposed along the south side of the valley of Buck Creek (pl. 1) east of the limits of the Andersonville district; here it has an average thickness of less than 30 feet. Only the upper part of the formation is exposed in the valley of Mills Creek to the southeast; exposures in this valley are few and extremely poor. Because most of the Flint River valley is covered by river-terrace deposits, Buck Creek and Mills Creek valleys afford the only exposures of the Nanafalia Formation in the area between Oglethorpe and the Andersonville district. East of the Flint River and south of the town of Montezuma, the Nanafalia Formation is also largely covered by alluvial terrace deposits and by younger Tertiary sediments. A wide terrace plain about 80 feet above the Flint River occupies much of this area. The upper part of the formation crops out in the valleys of Spring Creek and Hogcrawl Creek. Clay deposits in the part of the Hogcrawl Creek valley south of the fault that extends eastward from the Andersonville district may be of economic importance.

North of Montezuma (pl. 1), the Nanafalia Formation and the Midway Group are exposed beneath the overlapping sand of the Claiborne Group in the valley of Beaver Creek and along a prominent escarpment that borders the Flint River on the east. The Nanafalia Formation as exposed along the escarpment generally consists of 10 to 25 feet of micaceous sand, kaolinitic sand, and kaolin. In a small area about 7 miles north of Montezuma, the Nanafalia Formation is as much as 60 feet thick and consists mostly of coarse yellow-brown to brown sand, much of which is indurated to a hard ferruginous sandstone. This sand presumably represents an accumulation in a sinkhole that was formed before or during the deposition of the Nanafalia sediments. About 9 miles north of Montezuma, the Nanafalia pinches out, and sand of the Claiborne Group rests directly on the Midway Group.

TUSCAHOMA FORMATION

The thickness of the Tuscahoma Formation remains nearly constant from Fort Gaines northeastward through the Springvale district, but beyond that it gradually thins until in the Andersonville district it wedges out completely. The following measured thicknesses illus-

$780-471-65-2$ 
trate this thinning: In the Bear Creek valley just northeast of the town of Weston, Webster County, 75 feet; in the Choctahatchee Creek valley northeast of Plains, Sumter County, 60 feet; in the Muckalee Creek valley 5 miles northwest of Americus, Sumter County, 30 feet; and in the Toteover Creek valley about 11/2 miles north of La Cross, Schley County, 17 feet. The formation also thins in a northwesterly direction, up the dip, and in the vicinity of Richland, Stewart County (pl. 1), only scattered remnants are present.

The basal part of the formation from the valley of Choctahatchee Creek southwestward is a sand, glauconitic in places. All the basal sand may have been glauconitic originally, the areas where glauconite is absent having been leached. Parts of the formation, especially the basal sand, are locally fossiliferous. From Muckalee Creek northeastward, the glauconitic sand is absent, and no fossils have been found.

Most of the Tuscahoma Formation in the area northeast of the Springvale district is composed of soft gray, yellow, and purplish-red fine argillaceous sand and dark-gray clayey silt and very fine sand. Poorly formed to well-formed laminae are characteristic.

\section{BASHI MARI MEMBER OF THE HATCHETIGBEE FORMATION}

The Bashi Marl Member is the only part of the Hatchetigbee Formation present in the area. Only two exposures positively identified as Bashi Marl Member are known in the area, both in Stewart County. One very poor exposure yielding silicified shells is just above a spring on the northeast side of the county road 2 miles N. $20^{\circ}$ E. of Troutman. The other exposure is in a cut on a county road in the southeast corner of the county, on the south side of Summerford Branch.

CLAIBORNE GROUP AND RESIDUUM OF LATER TERTIARY LIMESTONES

Sediments of Claiborne age and residues of younger Eocene and Oligocene limestones overlap the earlier Tertiary sediments and are present along most of the divides. North of the area mapped, both the Tuscahoma Formation and the Midway Group pinch out, and a sand of the Claiborne Group rests on the Providence Sand. However, as far south as Richland (pl. 1), the Claiborne rests directly on the Providence.

The Claiborne Group of middle Eocene age in the area mapped is represented only by an unmamed sand unit. The sand is as much as 100 feet thick southeast of Andersonville, but it is commonly 30 to 50 feet thick. It is a nearly pure unconsolidated quartz sand that is white to yellow and massive to crossbedded. Kaolin is present as lenses, fragments, and discontinuous thin beds, especially to the east. The Fort Valley Plateau described by Cooke (1925, p. 41-42) extends 
northeastward from the town of Montezuma in the northeastern part of the area. This intensely cultivated upland plain is underlain principally by the overlapping sand unit of the Claiborne Group. The typical white to yellow loose sand of this formation has been weathered to a depth of 10 to 20 feet to a firm brick-red clayey sand. Rather large lenses of sandy kaolin with an observed thickness of as much as 12 feet are present locally in the sand.

The sand unit of the Claiborne Group is overlain by distorted clay and other materials that probably constitute a residuum from solution of limestones of the Jackson Group of late Eocene age and of limestone of Oligocene age. The residuum in the area of plate 1 is similar to that in the Andersonville and Springvale districts. The stratigraphic classification of the post-Wilcox sediments is based on the results of regional statigraphic studies by MacNeil (1946, p. 62; 1947). The three post Wilcox units are mapped together in plate 1.

\section{STRUCTURE}

The regional dip in the area is southeastward at approximately 20 feet per mile and is measured on beds older than the Midway Group; but where these beds are concealed, the dip is obscured by irregular slumping and small-scale faulting caused by solution of limestone of the Midway Group.

\section{OCCURRENCES OF BAUXITE AND BAUXITIC CLAY}

A complete exploration for outcrops of bauxite was not attempted, but deposits found in the course of the mapping are briefly described in the following subsections. The deposits are known to be small, and no attempt was made to determine their exact size.

\section{QUITMAN COUNTY}

Two miles west of Hatcher station (pl. 1), pisolitic bauxitic clay crops out in the roadbed 400 feet south of the tracks of the Central of Georgia Railway. A surface sample analyzed by the Bureau of Mines contained 40 percent alumina and 40 percent silica. As this bauxitic clay is well above the general level of the surface of the Midway Group. in this area, it is probably not related to a sinkhole.

Bauxitic pisolites occur in a field road $1 \frac{1}{2}$ miles northwest of Enon Church and a quarter of a mile northeast of Georgia Route 50. Kaolin crops out on the side of a small knoll, 50 feet west of the pisolites and at a slightly higher altitude. In general, the surface of the Midway is higher than both the bauxite and the kaolin of this exposure, as: shown by the distribution of dark-red sandy soil that is character- 
istically formed from the Midway, so the pisolites may be remnants of a sinkhole deposit. An analysis of the pisolites shows 55 percent alumina and 11 percent silica.

Northwest of Enon Church are several small exposures of pisolitic kaolin and some bauxite pisolites, all below the general level of the surface of the Midway; these pisolites are probably preserved in sinkholes.

\section{STEWART COUNTY}

Two miles southwest of Troutman (pl.1), a small deposit of pisolitic nonbauxitic kaolin crops out on the southeast side of the road that runs along the southwest side of Sapp Mill Creek. A gully 50 feet north of the road exposes a body of very clean kaolin more than 150 feet long and more than 20 feet thick.

Two miles northwest of Troutman, bauxite occurs in a pasture on the Pritchett property. Large pisolites are scattered over the surface 400 feet south of the country road. No attempt was made to outline the limits of the deposit, but a single hand-auger hole, drilled under the direction of W. A. Beck of the Bureau of Mines, penetrated 6 feet of low-grade bauxite. Fragments of chert residual from weathering of the Midway Group occur in the pasture southeast of the bauxite and at the same altitude, a fact suggesting that the bauxite is in a sinkhole.

Low-grade pisolitic bauxite is exposed 1 mine south of Ben Daniel School in a ditch on the east side of the road. The bauxite lies between and at the same altitude as two fuller's earth pits in clay of the Midway. The deposit is clearly a sinkhole filling. The exposure is very small, and no holes were drilled here.

\section{WEBSTER COUNTY}

About half a mile from the west edge of Webster County (pl. 1), bauxite or bauxitic clay occurs on the Will Ethridge property about 600 feet north of a county road. Some mining was done at this locality during World War I, and the mine trench has been described by Smith $(1929$, p. 431). Gray somewhat waxy clay exposed in one part of the pit resembles some of the clays of the Midway Group, a fact indicating that the bauxite and kaolin may have formed in an ancient sink or dropped into one.

About 3,000 feet northwest of the mine pit, pisolitic bauxitic clay has been plowed up at one place on a gentle slope, and kaolin is exposed in nearby gullies to the southeast.

Four miles northeast of the town of Preston (pl. 1), oolitic bauxitic clay is exposed in the roadbed and north ditch of Georgia Route 153. The extent and thickness of the deposit are not known. A surface 
sample, analyzed by the Bureau of Mines, contained approximately 45 percent alumina and 34 percent silica.

Three and a half miles due east of Preston, pisolitic bauxite is exposed in the south ditch and roadbank of a dirt road. A hand-auger hole, drilled under the direction of W. A. Beck of the Bureau of Mines, was started at the top of the roadbank and penetrated 14 feet of highly bauxitic clay and bauxite. The hole was stopped in bauxite. The highest grade of material contained 56.7 percent alumina and 10.7 percent silica. The average content of iron oxide of all the samples obtained was less than 0.5 percent. A second boring, on a small knoll in a field southeast of the outcrop, penetrated only sand. About 75 feet east of the outcrop, gray clay of the Midway Group is exposed at a level slightly higher than that of the bauxite, a fact indicating that the bauxite was preserved in a sinkhole structure. This conclusion is supported by the observation that, between the outcrop of clay of the Midway and the outcrop of bauxite, exposed sands of the Nanafalia Formation dip steeply in the direction of the bauxite.

About $41 / 2$ miles southeast of Preston, along the nose of a low southeastward-trending ridge, several shallow washes expose kaolin. In one of these washes, scattered pisolites of bauxite were observed. Bauxite was not seen in place but may be present.

\section{MACON AND DOOLY COUNTIES}

No bauxite is known to occur in the Nanafalia Formation in areas adjacent to the Andersonville bauxite district on the northeast and east. Here the Nanafalia Formation decreases in thickness to an average of about 20 feet, and about 16 miles northeast of Andersonville, near Marshallville, the formation pinches out and is overlapped by sediments of middle and late Eocene age. Between Marshallville and Montezuma, kaolin in the Nanafalia crops out at several places along Beaver Creek.

In the hilly area north of Buck Creek (pl. 1), outliers of the Nanafalia Formation cap several of the highest hills. What may be a significant deposit of kaolin was noted in an outlier 2 miles east-northeast of the town of Ideal. Boulders of hard pisolitic kaolin that resemble bauxite are locally abundant near the top of this hill. A handauger hole started below the level of the hard kaolin penetrated 12 feet of light-gray kaolin having scattered iron stains; the kaolin becomes sandy in the lower part and grades into micaceous sand. An attempted boring at a higher level could not penetrate the hard kaolin.

In the area adjacent to and east of the southern part of the Andersonville district, the Nanafalia is probably thicker and may contain deposits of bauxite. As the formation in this area, however, is largely 
covered by alluvial terrace deposits or by younger Tertiary sediments, its thickness, general character, and possible bauxite content cannot be determined from surface examination. The area south of the eastward-trending fault in the lower valley of Hogerawl Creek, Macon and Dooly Counties, seems to offer the best possibilities of finding economically important deposits of bauxite in areas adjacent to the Andersonville district. This area, which is suggested for drill exploration, is part of a wide river-terrace plain, 320 to 335 feet above sea level, through which Hogcrawl Creek has cut a valley about 70 feet deep that exposes the underlying Nanafalia Formation. Kaolin crops out in several places along this part of the valley. The segment of this terrace plain lying between the fault and the area of outcrop of the Nanafalia shown on plate 1 should be prospected. A northeastward-trending strip about half a mile wide just southeast of the area mapped as Nanafalia should also be prospected.

\section{REFERENCES CITED}

Clark, L. D., 1965, Bauxite deposits of the Springvale district, Georgia: U.S. Geol. Survey Bull. 1199-F, 24 p .

Cooke, Wythe, 1925, The Coastal Plain, in LaFarge, Laurence, and others, The physical geography of Georgia : Georgia Geol. Survey Bull. 42, p. 19-54.

MacNeil, F. S., 1946, The Tertiary formations of Alabama: Southeastern Geol. Soc. Guidebook, 4th Field Trip, $91 \mathrm{p}$.

- 1947, Geologic map of the Tertiary and Quaternary formations of Georgia: U.S. Geol. Survey Oil and Gas Inv. Prelim. Map 72.

Smith, R. W., 1929, Sedimentary kaolins of the Coastal Plain of Georgia : Georgia Geol. Survey Bull. 44, 482 p.

Zapp, A. D., 1965, Bauxite deposits of the Andersonville district, Georgia: U.S. Geol. Survey Bull. 1199-G, 37 p. 

